\title{
Correction to: A multilevel longitudinal study of obsessive compulsive symptoms in adolescence: male gender and emotional stability as protective factors
}

Vasilis Stavropoulos ${ }^{1,2}$, Kathleen A. Moore $^{2}$, Helen Lazaratou ${ }^{1 *} \mathbb{C}$, Dimitris Dikeos ${ }^{1}$ and Rapson Gomez ${ }^{2}$

\section{Correction to: Ann Gen Psychiatry (2017) 16:42} https://doi.org/10.1186/s12991-017-0165-z

The original version of this article [1] unfortunately contained a mistake in the author name. The co-author's name should be Dimitris Dikeos instead of Dimitris Dikaios.

The original article has been corrected.

\section{Author details}

${ }^{1}$ National and Kapodistrian University of Athens, Vas Sofias 72, 11528 Athens,

Greece. ${ }^{2}$ Federation University Australia, Mount Helen, Ballarat, VIC, Australia.

The original article can be found online at https://doi.org/10.1186/s12991-017-0165-z.

\section{Publisher's Note \\ Springer Nature remains neutral with regard to jurisdictional claims in pub-} lished maps and institutional affiliations.

Received: 19 December 2017 Accepted: 19 December 2017

Published online: 04 January 2018

\section{Reference}

1. Stavropoulos V, Moore KA, Lazaratou H, Dikeos D, Gomez R. A multilevel longitudinal study of obsessive compulsive symptoms in adolescence: male gender and emotional stability as protective factors. Ann Gen Psychiatry. 2017;16:42. https://doi.org/10.1186/s12991-017-0165-z.

*Correspondence: elazar@med.uoa.gr

${ }^{1}$ National and Kapodistrian University of Athens, Vas Sofias 72,

11528 Athens, Greece

Full list of author information is available at the end of the article

(O) The Author(s) 2018. This article is distributed under the terms of the Creative Commons Attribution 4.0 International License (http://creativecommons.org/licenses/by/4.0/), which permits unrestricted use, distribution, and reproduction in any medium, provided you give appropriate credit to the original author(s) and the source, provide a link to the Creative Commons license, and indicate if changes were made. The Creative Commons Public Domain Dedication waiver (http://creativecommons.org/ publicdomain/zero/1.0/) applies to the data made available in this article, unless otherwise stated. 